\title{
COLLABORATIVE APPROACH AND SCIENTIFIC APPROACH IN TEACHING WRITING DESCRIPTIVE TEXT
}

\author{
Maulana Alif Gymnastiar', Yanuarti Apsari² \\ ${ }^{1}$ IKIP Siliwangi \\ ${ }^{2}$ IKIP Siliwangi \\ ${ }^{1}$ maulanaalifgymnastiar07@gmail.com, ${ }^{2}$ yanuar.apsari1@gmail.com
}

\begin{abstract}
This research paper entitled "Collaborative Approach and Scientific Approach in Teaching Writing Descriptive Text". The objectives of the study was to know wheter or not there was significant different between students who were taught by using Cooperative Script and those who were taught taught by using scientific approach. The method of this research was quantitative method and the design was quasi-experimental design with two groups. The population of this research was eight grade students' and the sample are VIII A and VIII C. The instruments used in this research were test, observation, and interview. In analyzing the data, the writer used SPSS. The results of this research shows that the Sig of $\mathrm{N}$-Gain test $(0,014)$ was lower than 0,05 . It means that Ho of this research was rejected. Thus, the researcher concluded that there were differences between students who were taught by using collaborative approach and those who were taught by using scientific approach.
\end{abstract}

Keywords: Collaborative Approach, Scientific Approach, Writing

\section{INTRODUCTION}

2013 curriculum is an educational system that applied in Indonesia. The curriculum in indonesia has been changing and developing in many times. Curriculum is basis of teaching and learning process, so every teaching-learning process has to follow the curriculum.

The implementation of 2013 curriculum, there are three related dimensions. They cannot be separated. They are planning, teaching learning process, and learning evaluation. The planning will establish the materials will be taught, the media will be choosen, and the method will be used in teaching learning process. In such away, the evaluation procedures will be used to know the product of teaching learning process and students' achievement.

Learning is the process of interaction between students, between students and educators, and between participants and other learning resource in a learning environtment that takes place educatively, so that students can build attitudes, knowledge and skills to achieve their intended goals. The learning process is a process that contain a series of activities ranging from planning, implementation to assessment.

In learning English, students are expected to be able to master all language skills of English; listening, speaking, reading, and writing. It is basic on the goal of teaching English. To be able to use English well, writing is one of the important skills. English writing becomes a more and more important in international communication. (sharples, 2003) who states that writing an activity that can be used is prefered by work in other skills of listening, speaking, and reading. This preparation can be made possible for words that have been used recevtively to come into productive use. 
In addition, (ramadhani, 2017) defined that the writing skills is more complex and difficult, requiring the mastery not only the grammatical and theoretically devices but also the conceptual and judgment. People need to learn English writing because it is a transforming thoughts and ideas into written form. Writing is influenced by some elements such as vocabularies, grammar, organization, spelling, and punctuation. Blanchard and Root (1998: 1) in Mundriyah and Parmawati (2016) state that learning to write in a new language is not always easy. It is challenging but is also fun.

One of the problems in writing might be caused by students feel bored because the techniques used by the teacher are monotonous. There are many students who felt sleepy when the teacher explained the materials. It maybe because the teachers do not use good technique or method in the class.

Based on the statement above, the use of various approaches and selection of the appropriate approach will give effect to the students' success in the mastering writing ability. but is considered to ineffective in its implementation because students' could not express their ability to write, which means students need an approach to fulfill the needed and to create more optimal study result. One of the learning approaches applied collaborative approach.

Collaborative Approach is process can refer to about how groups or pairs provide feedback to each other, what they search for help from each other, and how they discuss and negotiate strategies in pointing writing (Mulligan \& garofalo, 2011). Related to the techniques, collaborative approach has several techniques. One of them are Cooperative Script. In this technique students work in pairs and verbally to summarize material and support one anothers understanding and recall of the important facts and concepts contained in material read (A'la, 2016).

The other approach that can be used in learning process is Scientific Approach. Scientific approach is one of the approaches in the new curriculum in Indonesia, known as 2013 curriculum. The characteristic of scientific approach lies in the learning steps are observing, questioning, experimenting (collecting information), associating, and communicating. Scientific learning is expected that students are able to produce their own products and apply what they have learned in daily activities (hosnan, 2014).

Based on teaching experience, in general students have difficulty in understanding and getting information from a text. Some students said that learning English was difficult. Besides that they also have difficulty in determining the main ideas and answering questions based on the text.

Based on the problem, this study aims to know whether there is or not any significant difference between students who were taught by using collaborative approach and those who were taught by using scientific approach.

\section{The Importance of Writing}

Writing is the complex process it means that in writing learners have to consider many things to build a good writing result. (Harmer, 2004) states that there are many advantages of learning writing. Namely:

1. Writing is often not time-bound in the way conversation is it means that learners have longer time to think than in speaking activity. They can check their grammar patterns. 
2. Writing encourages learners to focus on accurate language use because they think as they write; it may provoke development well as they resolve problems which writing puts in their mind.

3. Writing is often used as a means of reinforcing language that has been thought. They use writing skill to make a note about what they have learn while learning process happens.

4. Writing is frequently useful as preparation for some other activity.

5. Writing can also be used as an integral part of larger activity where the focus is on something else such as language practice, acting out, or speaking.

Based on advantages of writing from Harmer above, writing is important skill for learners that must be owned. Writing skills also usefull for daily activities especially academic purposes or perhaps for professional context such as in the working world.

\section{Cooperative Script}

Cooperative is cooperation; acting or working together with a common purpose, willingness to be helpful or mutual assistance, while the script is writing a text of a play, speech, or a paper document. Cooperative script is method refers to a form of collaborative learning in pairs, where the students work in pairs and orally summarizing section of material studied (Suprijono, 2015). Method is a way of doing strategy in teaching that used by the teacher about subject matter at the higher cognitive (Bull \& vicroria, 2008).

Cooperative script can define as when two people cooperatively, their explanation, role and prior knowledge to the information to be discussed can potentially affect retention. In addition, a cooperative experience has the potential facilitate subsequent individual study (idrus, 2014).

\section{Steps of Cooperative Script}

The eight steps as proposed by (Muliadi, 2017) are elaborate as follows:

1. Teachers divide students to group.

2. The teacher distributes the materials of each student to read and create summary.

3. Teachers and students determine who first role and speakers and whom the master divides students into.

4. The teacher distributes the listeners as a listener.

5. The speakers read the summary as completely as possible listeners listen to the basic ideas that are incomplete and helpful recall the main ideas and relate them to other material.

6. Exchanging roles as speakers converted to listeners.

7. Students' conclusion together with teacher.

8. Cover.

\section{The Advantages and Disadvantages Cooperative Script}

There are advantages of cooperative script learning model as sproposed by (A'la, 2016) as follow:

1. Train hearing and accuracy

2. Each students' gets a role

3. Train other to reveal the faults of others.

In addition, (A'la, 2016) also mention several disadvantageous of cooperative script as follows. 1 . it is only used for certain subject

2. Only two do (not involving the whole class so the correction is limited to the two persons only).

Based on the statement above, cooperative script method which attractive and become a world view, this method not only as a concept but also a technique to improve the interaction or 
cooperation students, many people who use this method, because the method is very varied, active, and create a joyful learning. It will make students can create a small group or in pairs. They will read the text that teacher given and then students should make summary of the material. It is a respond as listener and speaker to talk the subject. It means that one of them will orally summarize and the other listen correcting the summarize and help their partner if there something wrong in the summarize that they have made.

\section{Scientific Learning Approach}

Scientific approach is a scientific and inquiry approach, where students act direct either individually or in groups to explore the concept and principles during the learning activities and the teacher's task is to direct the learning process performed by the student and provide any correction to the concepts and principles which students have been obtained (Hidayah, 2013). Scientific approach is a learning process that is designed in such a way that students actively construct concepts, laws or principles through the stages of observing (to identify or find problems), formulate problems, submit or formulas hypotheses, collect the data with various techniques, analyze data, draw conclusions and communicate the concepts or principles that was discovered (Kurinasih, 2014). These two ideas became the basic of using scientific approach to be the basis implementing the 2013 curriculum.

Based on several explanations from experts, it can be concluded that scientific approach is a form of approach on developing students' religious aspect, social attitudes, knowledge and skills in applying subject matter. In this approach students are no longer used as learning objects, but are used as subjects of learning, teachers are only facilitators and motivators. The teacher does not need to explain more about the materials. In this study, the writer tries to compare the use cooperative script method model of Collaborative Learning Approach and Scientific approach as the basis approach on 2013 curriculum in a course.

\section{Characteristics of Scientific Approach}

(Kurinasih, 2014) stated that scientific approach has several characteristics, namely:

1. Students centered

2. Involving science skills process in constructing concepts, laws and principles.

3. Involves potential cognitive processes in stimulating the development of the intellect, especially the high-level thinking skills of students.

4. Can develop students' character.

\section{The Principles of Scientific Approach}

There are several principles of scientific approach as proposed by (Kurinasih, 2014), namely:

1. Students-centered learning.

2. Forms a student's concept.

3. Avoid verbalism.

4. Provides opportunities for students to assimilate and accommodate the concepts, laws and principles.

5. Encourages the increasing process of students' thinking skills.

6. Increases students learning motivation and teacher teaching motivation.

7. Provide opportunities for students to practice the students' skills communication

\section{The Stages of Scientific Approach}

The learning process of scientific approach has been arranged by Ministry of Education in Indonesia. Indonesian Ministry of education conveyed through Peraturan Pendidikan dan 


\section{Volume 2, No. 6, November 2019 pp 869-878

Kebudayaan (Permendikbud) No. 81 A on 2013 attachment IV, the learning Process consists of five main learning activities, namely:

\section{Observing}

In the process of observing, students are expected be able to witness what the teacher presents, for example; when the teacher present pictures, videos, or films related with the material, also when the teacher performs the simulation.

\section{Questioning}

After students observing, then students formulate questions for what the teacher has shown. With questioning, students are expected will pay more attention to the material and be able to find their own answers to the questions.

\section{Collecting the Information}

At this activity, the next task of students is collecting the information. The information can be obtained from various learning sources, such as books, internet, etc. this activity the students required to more active in the learning process with working together with a group.

\section{Associating}

After getting enough information, then students in a group share themselves task for associating and processing the information that has been obtained in a group report.

\section{Communicating}

In this activity, students are expected be able to communicate with other groups about that has been processed before. This activity is the main of science that students are expected to exchange information with other groups. Because this activity will create the condition where the students can be more active and get better students' outcome.

\section{METHOD}

The method of this research is Quantitative Research Method. According to (allaga \& gunderson, 2002) quantitative research is an inquiry into a social problem, explain phenomena by gethering numerical data that are analysed using mathematically based method e.g. in particular statistics. Quantitative research involves the use of computational, statistical, mathematical tools to derive result. The design of this research is Quasi Experimental Design. According to (sugiyono, 2010) quasi- experimental non- equivalent, pre-test and post-test design is used when study want to see the effect of a treatment where experimental and control group are not choosen randomly. In quasi experimental design, to collect the data, this research used two classes as follows:

The population of this research at Madrasah Tsanawiyah Al-Musyahadah Cimahi is the Eight grade students of 2018/2019 academic year which consist of 95 students in three classes. The sample of this research was two classes of eighth grade students of MTS Al-Musyahadah in academic year 2018/2019. The class were VIII A and VIII C. Each classes consisted of 30 students for VIII A and 30 students for VIII C.

In addition, the data were collected by using test. The researchers used written test to measure students' writing skill in understanding material which is given. In this test, the researcher give pre-test to know the students' writing skill about descriptive text before the treatment given by researcher. After the treatment given to the students, the researcher give post test to know how far the students' writing skill about descriptive text. Then, to analyze the data, the researchers 
used SPSS version 23. SPSS (Statistical Package for the Social Sciences) is an program used to perform advanced statistical analysis.

\section{RESULTS AND DISCUSSION}

\section{Results}

\section{Descriptive Statistic}

The result of descriptive statistic was used to find minimum, maximum, mean, and standard division using SPSS version 23. The descriptive statistic between experimental class and control class as follows:

Table .1 Descriptive Statistic

\begin{tabular}{|c|c|c|c|c|c|c|c|}
\hline \multirow{2}{*}{$\begin{array}{c}\text { Variable } \\
\begin{array}{c}\text { Writing } \\
\text { skill }\end{array}\end{array}$} & & \multicolumn{3}{|c|}{ Experimental class } & \multicolumn{3}{|c|}{ Control class } \\
\hline & & $\begin{array}{l}\text { Pre } \\
\text { Test }\end{array}$ & $\begin{array}{l}\text { Pos } \\
\text { Test }\end{array}$ & $\mathbf{N}$ gain & Pretest & postest & $\mathbf{N}$ gain \\
\hline & $\mathbf{N}$ & 30 & 30 & & 30 & 30 & \\
\hline & Mean & 64,53 & 75,47 & 0,3067 & 56,87 & 75,93 & 0,4367 \\
\hline & $\mathbf{X} \max$ & 70 & 90 & $\mathbf{0 , 8 0}$ & 74 & 87 & $\mathbf{0 , 7 0}$ \\
\hline & $\mathrm{X} \min$ & 49 & 62 & $-0,20$ & 42 & 64 & $\mathbf{0 , 0 0}$ \\
\hline & $\begin{array}{l}\text { Std.Deviati } \\
\text { on }\end{array}$ & 4,485 & 7,565 & & 8,748 & 7,239 & \\
\hline
\end{tabular}

Based on the table of descriptive statistic showed that minimum score pretest of experimental class was 49 and maximum score was 70 . The minimum score posttest was 62 and maximum score was 90. Meanwhile, the minimum score $\mathrm{N}$-gain pretest was $-0,20$ and maximum 0,80 . Mean of pretest was 64,53 , posttest was 75,47 and $\mathrm{N}$-gain was 0,30 . Standard deviation of pretest in experimental class was 4,485 and posttest was 7,565.

On the other hand, minimum score pretest of control class was 42 and maximum 74 . The minimum score posttest was 64 and maximum score was 87 . Meanwhile, the minimum N-gain score pretest was 0,00 and maximum 0,70 . Mean of pretest was 56,87, posttest was 75,93 and $\mathrm{N}$-gain was 0,43 . Standard deviation pretest in control class was 8,748 and posttest was 7,239.

The both data show that the maximum and mean score posttest was higher than pretest. It meant that there was improvement of students writing skill in both classes. However, the difference between them cannot be found out yet. This will be investigated and explained in the next section.

\section{Normality Distribution Test of Pretest}

To find out the data of the research was normal or not the researcher used SPSS program software. It can be said the data was normal if the significance values higher than 0,05 . It means if the data is lower than 0,05 the data is not normal distribution. The table of normal distribution test as below: 
Tabel .2 Normal Distribution Test of Pre-Test.

Tests of Normality

\begin{tabular}{|ll|r|r|r|r|r|r|}
\hline \multirow{2}{*}{} & \multirow{2}{*}{} & \multicolumn{3}{|c|}{ Kolmogorov-Smirnov $^{\mathrm{a}}$} & \multicolumn{3}{c|}{ Shapiro-Wilk } \\
\cline { 2 - 8 } & Statistic & \multicolumn{1}{c|}{$\mathrm{df}$} & \multicolumn{1}{c|}{ Sig. } & \multicolumn{1}{c|}{ Statistic } & \multicolumn{1}{c|}{ df } & \multicolumn{1}{c|}{ Sig. } \\
\hline pretest & experiement & .219 & 30 & .001 & .869 & 30 & .002 \\
& control & .111 & 30 & $.200^{\star}$ & .956 & 30 & .244 \\
\hline
\end{tabular}

*. This is a lower bound of the true significance.

a. Lilliefors Significance Correction

Based on Kolmogorov-Smirnov table, the significant value of experimental class was 0.001 lower than 0.05 and significant value of control class was 0.200 higher than 0.05 . It means that the data of the experimental class was not normally distributed, while the data in control class was normally distributed. It continues to the analyzed to Mann Whitney Test.

\section{Mann Whitney Test of Pretest}

As one the data was not normal, Mann-Whitney test was used. Mann-Whitney is not parametric test that is used to investigate whether or not the Ho of this study is accepted or rejected. Related to the hypotheses used in the pretest of this research, it is explained as follows:

Ho : $\mu 1=\mu 2$ (there is no difference in students' writing abilities Collaborative Approach (Experimental Class) and Scientific Approach (Control Class)

H1 : $\mu 1 \neq \mu 2$ (there is difference in students' writing abilities of Collaborative Approach (Experimental Class) and Scientific Approach (Control Class)

Ho was accepted if significance value of asymp (2-tailed) was higher than 0.05 . On the other hand, it was rejected if asymp (2-tailed) was lower than 0.05 .

Table .3 Mann Whitney of Pretest

Test Statistics $^{a}$

\begin{tabular}{|l|r|}
\hline & \multicolumn{1}{|c|}{ ngain } \\
\hline Mann-Whitney U & 286.500 \\
Wilcoxon W & 751.500 \\
Z & -2.448 \\
Asymp. Sig. (2-tailed) & .014 \\
\hline
\end{tabular}

a. Grouping Variable: writing

Based on the table above, significance value of (2-tailed) was 0.014. It means that the value was lower than 0.05. As the result of Mann-Whitney test in this research, it can be concluded that Ho was rejected. Because there was a difference between writing abilities in experimental class (Collaborative Approach) and control class (Scientific Approach).

\section{Data Statistical of N-Gain}

\section{Normality test}


To find out the data of the research was normal or not, the researcher used SPSS program software. Can be said the data was normal if the significance values higher than 0,05 . It means if the data is lower than 0,05 the data is not normally distribution. The table of normal distribution of N-Gain test as below:

Table .4 Test of Normality N-Gain

Tests of Normality

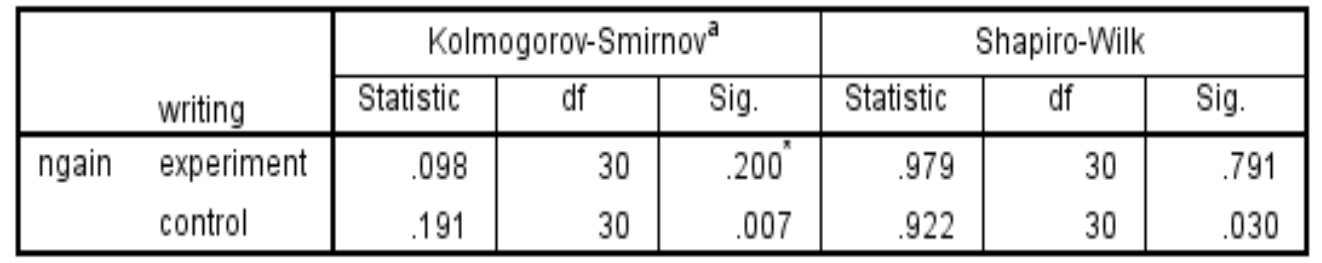

*. This is a lower bound of the true significance.

a. Lilliefors Significance Correction

Based on Kolmogorov-Smirnov table, the significance value of experimental class was 0.200 higher than 0.05 , and significance value of control class was 0.007 lower than 0.05 . It means the data of experimental class was normal distributed and the control class was not normally distributed. Because one of the data N-Gain was not normally distributed, it continued to the non-parametric or Mann-Whitney test.

\section{Mann-Whitney Test (N-Gain)}

Non-Parametric test or Mann-Whitney test was used to find the difference between students' writing skill who were taught by using collaborative approach and those who were taught by using scientific approach. The result of Mann-Whitney test in this result is presented as follows:

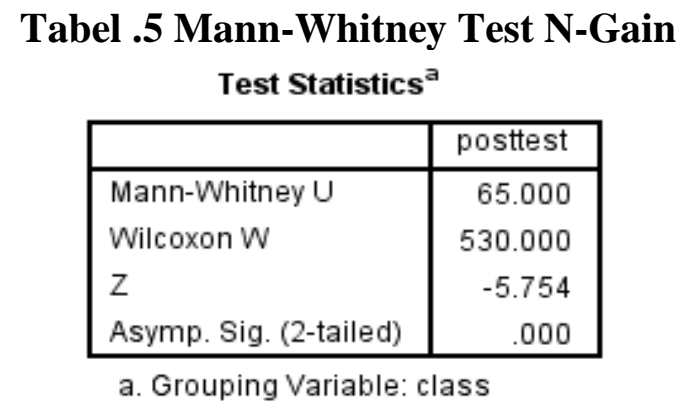

Based on the table above, significance value of 2-tailed was 0.000 . It means that the value was lower than 0.05. As the result of Mann-Whitney test in this research, it can be concluded that Ho was rejected. This means that there was the difference between students' writing skill who were taught by using collaborative approach and those who were taught by using scientific approach.

\section{Discussion}

The analysis result shows that Ho of this research was rejected. The significant value of Mann Whitney of $\mathrm{N}$-Gain $(0,014)$ is lower than 0,05 . This indicates that there is the difference between students' writing skill who were taught by using collaborative approach and those who were taught by using scientific approach. The difference can be seen from the mean score of the test, by which the N-GAIN mean of experimental class $(0,30)$ is lower than control class $(0,43)$. 
In addition, teh data also revealed several advantages in implementing Cooperative Script. Students seemed enjoyed and motivated in learning activities. It is supported by (A'la, 2016) who says that the advantages of using cooperative script technique is train hearing and accuracy, each students' gets a role, train other to reveal the faults of others. In contrast, in the implementation of cooperative script, there are difficulties for researcher to handle the class. Even though the use of cooperative script can improve students' writing skill and create interactive classroom atmosphere, the interview result shows that the students still found the difficulties in writing. This is caused by their limited vocabulary. They are also had difficulties in spelling and grammar. On the contrary, the result of the post-test showed there was a significant different between experimental class and control class, the experimental class got higher score than control class.

\section{CONCLUSION}

The result of statistical data shows that Ho is rejected. The significance value of Mann Whitney test $(0,00)$ is lower than 0,05 . This indicate that there is difference between students' speaking skill who are taught by using collaborative approach and those who are taught by using scientific approach. Regarding this, based on N-Gain data, the improvement of students' who are taught by using collaborative approach is better than those who are taught by using scientific approach.

The implementation in experimental group use collaborative approach through cooperative script can create more enjoyable atmosphere than scientific approach. The students seem to be more enthusiast in learning because that was something new for them. They are also more motivated to write and if they have finished to discuss, they should share their written/work in front of the class. The steps in scientific approach were observing, questioning, experimenting, associating, and communicating. The researcher gave the students text and ask them to identified the generic structure of the text, also ask the students to write descriptive text individually and after that they need to do presentation in front of the class and the other students gave feedback comments.

\section{ACKNOWLEDGMENTS}

First of all thanks to ALLAH S.W.T for his mercy and guidence in giving me full strength to complete this article. Even facing with some difficulties in completing this article, I still managed to complete it. A lot of thanks to my supervisor for all of this support and guidence in helping me to finish my article. Then, I would like to thanks to my parents. In addition, grateful acknoledgment to my friends who help me to finish this article. Thank you so much. Hopefully, this research can be useful for the reader. The constructive suggestion, criticism from the reader are warmly welcome.

\section{REFERENCES}

A'la. (2016). quantum teaching. yogyakarta: diva press.

Allaga, \& gunderson. (2002). intractive statistic.

Bull, \& vicroria. (2008). oxford learners pocket dictionary (4th ed.). oxford university press. Harmer, J. (2004). how to teach writing. united kingdom: pearson educaton ltd.

Hidayah, N. (2013). pengetian dan langkah langkah pembelajaran scientific. Retrieved from http://www.nurulhidayah.net/pengertian-danlangkahlangkahpembelajaranscientific.html

Hosnan. (2014). pendekatan scientific dan kontekstual dalam pembelajaran abad 21. 
Idrus. (2014). using coopertive script technique to increas the reading comprehension of the second years students of smp 3 duampanua kabupaten pinrang. uin alauddin makasar.

Kurinasih. (2014). sukses mengimplementasikan kurikulum 2013. kata pena.

Muliadi. (2017). Cooperative Script Learning Model to Improving Student Listening Skills. 7(3), 98-107. https://doi.org/10.9790/7388-07030498107

Mulligan, \& garofalo. (2011). a collaborative writing approach: methodology and students assessment. ritsumeikan university.

Mundriyah, M., \& Parmawati, A. (2016). Using Think-Pair-Share (Tps) To Improve Students'writing Creativity (A Classroom Action Research In The Second Semester Students Of Stkip Siliwangi Bandung). P2m Stkip Siliwangi, 3(2), 84-91.

Ramadhani, A. . (2017). the effect of collaborative writing strategy on students achievement in writing recount text in mts al washliyah tembung.

Sharples. (2003). how we write writing as creative. new york: routledge.

Sugiyono. (2010). metode penelitian kualitatif kuantitatif dan $R \& D$. bandung: alfa beta.

Suprijono. (2015). cooperative learing teori dan aplikasi PAIKEM. yogyakarta: pustaka belajar. 